\title{
REMARKS ON THE UNIFORMITY OF NATURAL LAW CONCEPTS IN THE HISTORY OF LEGAL PHILOSOPHY
}

\section{Laurens Winkel***}

\section{ABSTRACT}

The aim of this paper is to investigate different meanings of the concept of natural law in the history of ideas since the early Greeks. Texts of Plato, Aristotle and the Stoics are briefly examined, followed by an analysis of some well-known texts of Roman law. Although natural law is generally-speaking linked with human equality, it appears from this investigation that sometimes in antiquity, natural law is also invoked to underpin human inequality. A parallel is drawn with natural-law philosophy in the twentieth century. On the one hand, we find that the link between natural law and human equality is most often maintained, but on the other hand we also find invocations of natural law to justify societal exclusion. Is this the reason for the intrinsic weakness of natural-law philosophy?

Keywords: Natural law; Greek philosophy; Roman law; equality

* Emeritus Professor, School of Law, Erasmus University Rotterdam.

** I would like to thank Dr René Brouwer for his useful comments. A shorter, slightly different version of this paper was published in French in the Revue historique de droit français et étranger IV série, 2015, 341-350. 
1. Modern natural-law theory is often linked with values such as liberty and equality. Furthermore, within this line of thought, natural law is most often considered eternal and unchangeable. ${ }^{1}$ The Declaration of Human Rights of the French Revolution, the European Convention on Human Rights (Rome, 1950) and the International Covenant on Civil and Political Rights (New York, 1966) provide evidence for this position. In this contribution, I will examine the extent to which these two statements are borne out by the complexity of our classical sources that mention "law and nature". A slightly forgotten book, written in 1922 by Adolf Menzel² (1857-1938) who was at the time a professor of constitutional law at the University of Vienna, will be our guide. ${ }^{3}$ Menzel had explained the extent to which the conception of natural law had been debated constantly in classical Greece. From his analysis, it would appear that many different conceptions on natural law were already in competition during this time. Although the different conceptions on natural law in classical times have been meticulously examined in a book by the German scholar Erik Wolf, ${ }^{4}$ and in spite of the abundance of secondary literature, ${ }^{5}$ it seems worthwhile to me to re-open this topic, also in view of some aspects on natural law in recent history.

2. The Ionic philosophy regarding Nature, in which the elements water, fire, air, and earth jostle for supremacy, provided the basis for Greek philosophy. ${ }^{6}$ Conceptions of nomos and physis played an important role in this philosophy. ${ }^{7}$ As a result, the original question in Greek philosophy before Socrates' times was: What does Nature teach us? Does it teach us equality or in fact inequality? The sophists Thrasymachos $^{8}$ and Callicles ${ }^{9}$ contended that Nature teaches us inequality. To this I am adding the key points of the ideas of Callicles, which addressed the contrast between nomos and physis. ${ }^{10}$ For a recent explanation of this text we can turn to the

1 Flückiger 1954: passim; Jones 1956: 37ff. Exceptions: Montesquieu and Stammler who assume forms of natural law "at variance". See Montesquieu De l'esprit des lois Book XIV-XVIII; $c f$ Donati 1990: 94 n 57 (according to Donati Montesquieu does not adhere to a natural law theory in the strict sense); and Stammler 1902: 93ff.

2 Menzel 1922.

3 Brauneder 1994: 104f.

4 Wolf 1959. During the thirties Wolf was a member of the NSDAP, but after 1937 he changed his views and adhered to the Bekennende Kirche, one of the centres of intellectual resistance against Nazism in Germany. See Müller 1987: 95 and Hollerbach 1979: 455-461.

5 Messmer 1950; Donati 1990: n 1; Waldstein 2010. Messmer, Donati and Waldstein seem to adhere to a catholic and absolute doctrine of natural law. See for Messmer: Klose, Schambeck \& Weiler 1985.

6 Guthrie 1962: 5ff.

7 Heinimann 1945: 110f, 123f.

8 Trasymachos taught that justice is an illusion without value, see Hoffmann 1997: 98 (review: Winkel 2000).

9 Hoffmann 1997: 124.

10 According to current opinions the historical existence of Callicles is not beyond doubt. See Praechter 1926: 55 with further references (quoted as Überweg-Praechter); Hoffmann 1997: 111. 
comments of Terence Irwin and Joachim Dalfen. ${ }^{11}$ Socrates tried to refute the views of Callicles (Gorg 489ff) and, in doing so, he introduced the notion of equality into the discussion. ${ }^{12}$ Accordingly Socrates, Plato and somewhat later Aristotle, developed a sort of rationalism which leads to a conception of natural law that is limited to the human equality. According to Schrage this equality is not automatically applicable to political views, however, since certain forms of inequality, such as slavery, are allowed: ${ }^{13}$

\section{Plato Gorgias 483 B-C}

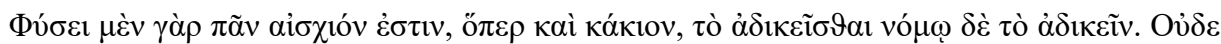

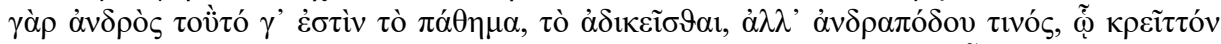

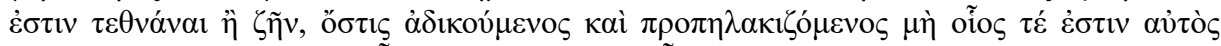

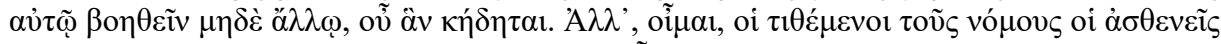

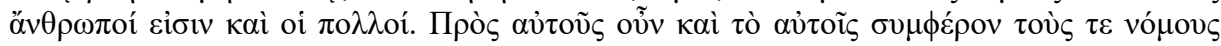

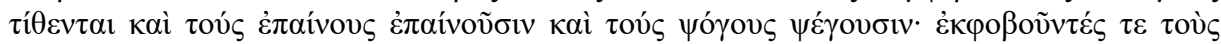

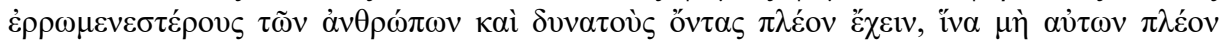

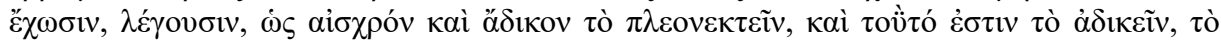

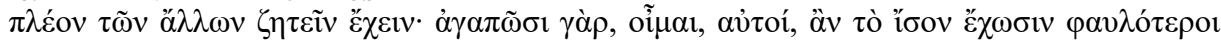

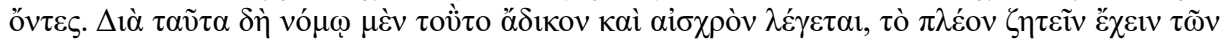

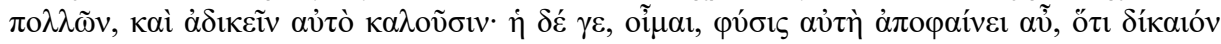

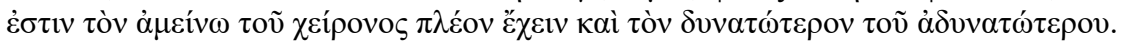

For by nature ("physis") everything that is worse is more shameful, suffering wrong for instance, but by convention ("nomos") it is more shameful to do it. For to suffer wrong is not even fit for a man, but only for a slave, for whom it is better to be dead than alive, since when wronged and outraged he is unable to help himself or any other for whom he cares. But in my opinion, those who framed the laws are the weaker folk, the majority. And, accordingly, they frame the laws for themselves and their own advantage, and so too with their approval and censure, and to prevent the stronger who are able to overreach them from gaining the advantage over them, they frighten them by saying that to overreach others is shameful and evil, and injustice consists in seeking the advantage over others. For they are satisfied, I suppose, if being inferior they enjoy equality of status. That is the reason why seeking an advantage over the many is by convention (nomos) said to be wrong and shameful, and they call it injustice. But in my view nature (physis) herself makes it plain that it is right for the better to have the advantage over the worse, the more able over the less. (Translation Hamilton \& Huntington Cairns, Princeton, 1978.)

3. The debate between Socrates and Callicles is still echoed in later literature. This appears, for example, in a text of Aristotle, the Sophistic Refutations, already analysed by Menzel:

\section{Aristoteles, Sophistici Elenchi 173 a 7-19}

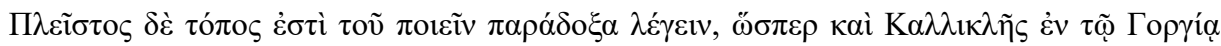

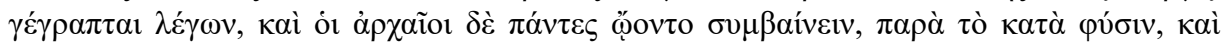

11 Irwin 1979: 172ff; Dalfen 2004: 320ff.

12 Jones 1977: 49-50, citing Plato, Menexenus 239 A. See, further, Frede 1996: 157-174 and in the same book the article of Sorabji 1996: 311-334.

13 1975: esp 17ff. 


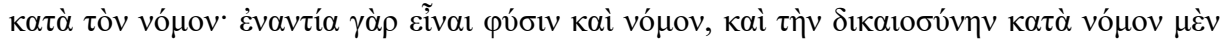

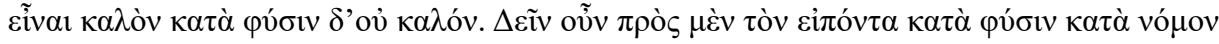

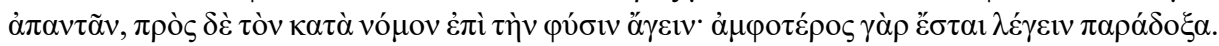

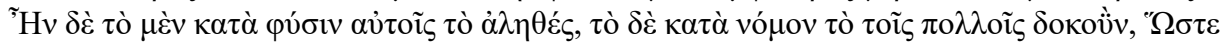

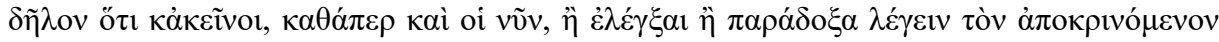

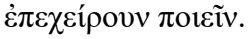

The widest range of common-place argument for leading men into paradoxical statement is that which depends on the standards of Nature and of the Law so that too Callicles is drawn as arguing in the Gorgias, and that all the men of old supposed the result to come about: for nature (they said) and law are opposites, and justice is a fine thing by a legal standard, but not by that of nature. Accordingly, they said, the man whose statement agrees with the standard of nature you should meet by the standard of the law, but the man who agrees with the law by leading him to the facts of nature: for in both ways paradoxical statements may be committed. In their view the standard of nature was the truth, while that of the law was the opinion held by the majority. So that it is clear that they, too, used to try either to refute the answerer or to make him make paradoxical statements, just as the men of to-day do as well. (Translation by WA Packard, with one correction.)

Menzel has pointed to the fact that according to Socrates, Callicles is the one who makes use of paradoxes, whilst according to Plato, it is Callicles who reproaches Socrates for having resorted to paradoxes. ${ }^{14}$ Then both can be right: when one of them discusses the level of the physis, while the other discusses the level of the nomos. In my view, this text could even provide us with arguments that make Callicles a historical person, a disputed question in the history of philosophy. ${ }^{15}$

A second echo of Callicles may be found in the work of Aulus Gellius (about 175 $\mathrm{AD})$, one generation before Ulpian. This text, too, was already quoted by Menzel:

Aulus Gellius Noctes Atticae 1022 1-2: Plato, veritatis homo amicissimus eiusque omnibus exhibendae promptissimus, quae omnino dici possint in desides istos ignavosque, qui obtentu philosophiae nominis inutile otium et linguae vitaeque tenebras secuntur, ex persona quidem non gravi neque idonea, vere tamen ingenueque dixit. 2. Nam etsi Callicles, quem dicere haec facit, verae philosophiae ignarus inhonesta indignaque in philosophos confert, proinde tamen accipienda sunt, quae dicuntur, ut nos sensim moneri intellegamus, ne ipsi quoque culpationes huiuscemodi mereamur neve inerti inanique desidia cultum et studium philosophiae mentiamur.

Plato, a man most devoted to the truth and most ready to point it out to all, has said truly and nobly, though not from the mouth of a dignified or suitable character, all that in general may be said against those idle and worthless fellows, who, sheltered under the name of philosophy, follow profitless idleness and darkness of speech and life. 2. For although Callicles, whom he makes his speaker, being ignorant of true philosophy, heaps dishonourable and undeserved abuse upon philosophers, yet what he says is to be taken

14 Menzel 1922: 15; De Romilly 1989: 114.

15 In this train of thought Überweg-Praechter 1926: 127; see also Hoffmann 1997: $111 \mathrm{ff}$. He gives an overview of the arguments in favour of Callicles as an historical person. 
in such a way that we may gradually come to understand it as a warning to ourselves not to deserve such reproofs, and not by idle and foolish sloth to feign the pursuit and cultivation of philosophy. (Translation JC Rolfe, Loeb ed.)

Callicles's philosophy is considered here to be "wrong and untrue". This has led us to look into a text of Ulpian which demonstrates that the contrast between true and false philosophy is also important. In this text Ulpian describes the Jurisprudence as the true philosophy. ${ }^{16}$

4. In the Nicomachean Ethics Aristotle in turn deals with the contrast between nomos and physis and as such he endeavours to give an argumentation for the definition that has become the standard for the unchangeable Natural Law:

\section{Aristoteles Ethica Nicomacheia V 7 1-3 1134 b 19-27}

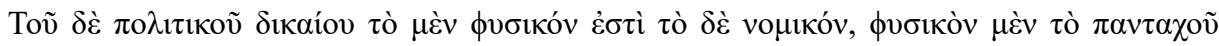

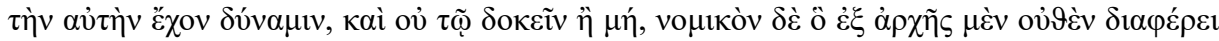

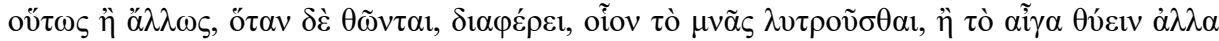

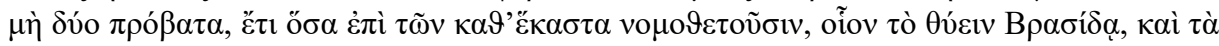

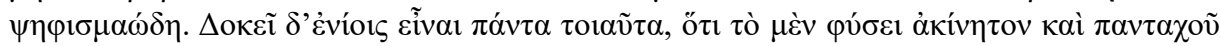

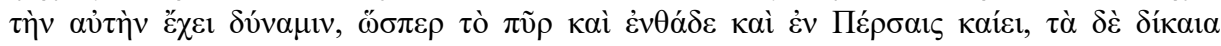

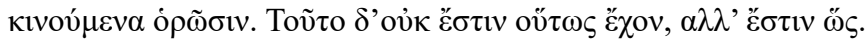

Political justice is of two kinds, one natural, the other conventional. A rule of justice is natural that has the same validity everywhere and does not depend on our accepting it or not. A rule is conventional that in the first instance may be settled in one way or the other indifferently, though having once being settled it is not indifferent: for example that the ransom for a prisoner shall be a mina; that a sacrifice shall consist of a goat and not of two sheep; and any regulations enacted for particular cases, for instance the sacrifice in honour of Brasidas, and ordinances in the nature of special decrees. Some people think that all rules of justice are merely conventional, because whereas a law of nature is immutable and has the same validity everywhere, as fire burns both here and in Persia, rules of justice are seen to vary. That rules of justice vary is not absolutely true, but only with qualifications. (Translation H Rackham, Loeb ed.)

According to Aristotle, law was originally neutral on the ethical level. ${ }^{17}$ When Aristotle started his career as the Secretary of Nature, ${ }^{18}$ he does not yet differentiate between juridical law and natural law which is a theme that has recently been dealt with by Jan Schröder. ${ }^{19}$ According to him, the distinction in the inner substance of

16 D 111 1: "Cuius merito quis nos sacerdotes appellet: iustitiam namque colimus et boni et aequi notitiam profitemur, aequum ab iniquo separantes, licitum ab illicito discernentes, bonos non solum metu poenarum, verum etiam praemiorum quoque exhortatione efficere cupientes, veram nisi fallor philosophiam, non simulatam affectantes.” See Schermaier 1993: 303-322.

17 Here we are at the origin of the distinction in common law between mala per se and mala prohibita, see also Thomas Aq, Summa Theologiae, q 100, a 3.

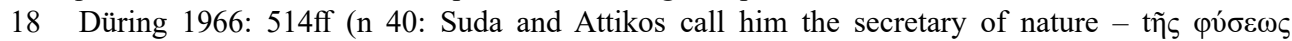
$\gamma \rho \alpha \mu \mu \alpha \tau \varepsilon \dot{\varsigma} \varsigma)$.

19 Schröder 2004. 
the conception of "law in nature" and "statutory law" has not been introduced before $1650 .{ }^{20}$

The opposition between committing an injustice and to suffer injustice, a theme dealt with in the Platonic dialogue Gorgias, is also used by Aristotle when he examines the question of righteous behaviour:

Aristoteles Ethica Nicomacheia V 5171133 b 29-32

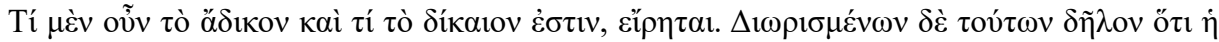

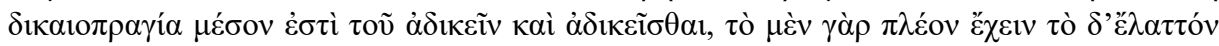
$\dot{\varepsilon} \sigma \tau \imath$.

We have now stated what justice and injustice are in principle. From the definition given, it is plain that just conduct is a mean between doing and suffering injustice, for the former is to have too much and the latter to have too little. (Translation H Rackham, Loeb ed.)

In his explanation of the theory on "righteous behaviour", Aristotle also deals with the distinction between "committing injustice" and "suffering injustice" - a theme which is discussed in a passage in the Dialogue Gorgias and is part of the basic thesis of Callicles. In this sense, the theory of Callicles has been one of the sources for the theory of Aristotle with regard to the doctrine of the Mean which he had introduced in the second book on the Nicomachean Ethics. ${ }^{21}$

5. In Stoic philosophy the words of Callicles do not resound anymore. The originally Platonic and Peripatetic rationalism is still accentuated very much, ${ }^{22}$ whilst the consistency (immutability) of natural law is even more accentuated than in the work of Aristotle. ${ }^{23}$ This consistency has a direct link with radical rationalism. Nature as a whole follows the logos and that also applies to the Norms. With regard to Stoic philosophy, a very well-known text is always quoted, of which unfortunately the history of its textual transmission has been quite neglected. The text reads as follows: ${ }^{24}$

20 Only with Immanuel Kant, at the end of the eighteenth century, are "is" and "ought" questions duly separated which led in the nineteenth century to several forms of legal positivism. A reappearance of cautious thoughts on natural law is only visible at the beginning of the twentieth century. Rudolf Stammler (quoted in $\mathrm{n} 2$ ) is an example.

21 For Aristotle's Theory of the Mean see Hardie 1980: 129ff and Manthe 1996: 1-31.

22 Forschner 1980: 150ff; see also Algra 2003: 265-296, esp 275ff.

23 See Villey 1953: 475-497. He examines the differences in the natural law theory between Aristotle and the Stoics. According to him natural law is universal for Aristotle, but restrained to human beings for the Stoics. In as far as he is right, see Ulpian's definitions of ius naturale and ius gentium in D 1111 1 $3-4$ and also Winkel 1993: 443-449. However, we do not agree with Villey when he states that natural law for Aristotle is in the first place legal, whereas for the Stoics it would belong to morals (Villey 1953: 487). This is, however, quite another topic to which we may come back on another occasion.

24 Flückiger 1954: 226; Büchner 1984: 126. Flückiger does not take into account the stoic origin of this text. See, also, Horsley 1978: 35-59. 


\section{Cicero De Re Publica 322}

Est quidem vera lex recta ratio naturae congruens, diffusa in omnes, constans, sempiterna, quae vocet ad officium iubendo, vetando a fraude deterreat; quae tamen neque probos frustra iubet aut vetat nec improbos iubendo aut vetando movet. huic legi nec obrogari fas est neque derogari ex hac aliquid licet neque tota abrogari potest, nec vero aut per senatum aut per populum solvi hac lege possumus, neque est quaerendus explanator aut interpres eius alius, nec erit alia lex Romae, alia Athenis, alia nunc, alia posthac, sed et omnes gentes et omni tempore una lex et sempiterna et immutabilis continebit, unusque erit communis quasi magister et imperator omnium deus, ille legis huius inventor, disceptator, lator; cui qui non parebit, ipse se fugiet ac naturam hominis aspernatus hoc ipso luet maximas poenas, etiamsi cetera supplicia, quae putantur, effugerit.

True law is right reason in agreement with nature; it is of universal application, unchanging and everlasting; it summons to the duty by its commands and averts from wrongdoing by its prohibitions. And it does not lay its commands or prohibitions upon good men in vain, though neither have any effect on the wicked. It is a sin to try to alter this law, nor is it allowed to attempt to repeal any part of it, and it is impossible to abolish it entirely. We cannot be freed from its obligations by senate or people, and we need not look outside ourselves for an expounder or interpreter of it. And there will not be different laws at Rome and at Athens, or different laws now and in the future, but one eternal and unchangeable law will be valid for all nations and all times, and there will be one master and ruler, that is God, over us all, for he is the author of this law, its promulgator, and its enforcing judge. Whoever is disobedient is fleeing from himself and denying his human nature, and by reason of this very fact he will suffer the worst penalties, even if he escapes from what is commonly considered punishment. (Translation CW Keyes, Loeb ed. The text is a reconstruction of Lactantius Institutiones Diviniae 68 6-9.)

We must be aware that the text of Cicero's Republic is a reconstruction and that this text was transmitted to us by a much later Christian author, Lactantius ( \pm 250-320 AD). According to Cicero, Natural Law stems from (human) reason, is unchangeable and independent of time and place. ${ }^{25}$ This implies that Natural Law is a direct consequence of the human reason without epistemological problems. ${ }^{26}$ In other words, the content of Natural Law is immediately accessible to all human beings and may be known to everybody. However, this conception of Natural Law has not always been predominant and Stoicism and Epicurism differ on that point. It is generally accepted that Stoicism has influenced the Christian doctrine which is visible, for example, in the work of St Augustine.

It is therefore understandable why the text of Cicero has been incorporated by Hans von Arnim into the collection of fragments on Stoicism (SVF 111, 325). Long and Sedley $^{27}$ indicated that its original context has not been handed down to us.

25 See Pizzorni 1985: 47-67.

26 Flückiger 1954: 377.

27 Long \& Sedley 2009a: fragment 67 S; $c f$ also Long \& Sedley 2009b: 128. The original context of this passage is lost. 
A large part of the text of the Republic by Cicero is missing. They furthermore call attention to its transmission by Lactanctius which is the "key" to understand the reference in this text to Monotheism. Later Stoicism accentuates even more the human reasoning which could explain why the legal sequence in Stoicism seems to be restricted to human beings. In order to understand this development in the history of Ideas, one could quote another text of Cicero, an annex to the previous one and also a text from De Finibus:

\section{Cicero De Re Publica 31119}

Esse enim hoc boni viri et iusti, tribuere id cuique, quod sit quoque dignum. Ecquid ergo primum mutis tribuemus belvis? Non enim mediocres viri, sed maxumi et docti, Pythagoras et Empedocles, unam omnium animantium condicionem iuris esse denuntiant clamantque inexpiabilis poenas impendere iis, a quibus violatum sit animal.

For, they say, it is the duty of a good and just man to give everyone that is his due. Well the, first of all, what is it, if anything, that we are to grant to dumb animals as their due? For it is not men of mediocre talents, but those who are eminent and learned, such as Pythagoras and Empedocles, who declare that the same principles of justice apply to all living creatures, and insist that inevitable penalties threaten those who injure an animal. (Translation CW Keyes, Loeb ed.)

This text must be compared with:

Cicero De Finibus 32067 (SVF 3 371) [S]ed quomodo hominum hominum inter homines iuris esse vincula putant, sic homini nihil iuris esse cum bestiis. Praeclare enim Chrysippus cetera nata esse hominum causa et deorum, eos autem communitatis et societatis suae, ut bestiis homines uti ad utilitatem suam possint sine iniuria ...

But just as they hold that man is united with man by the bonds of right, so they consider that no right exists as between man and beasts. For Chrysippus well said, that all other things were created for the sake of men and gods, but that these exist for their own mutual fellowship and society, so that men can make use of beasts for their own purposes without injustice. (Translation H Rackham, Loeb ed.)

In the first text it seems that the duties/responsibilities of mankind are also applicable to animals. And also the phrase - tribuere id cuique - resounds in the famous definition of Justice by Ulpian: suum cuique tribuere (D 1110$).{ }^{28}$ In the second text, Justice and the Sphere of Law are only applicable between human beings. This way of thinking is also reflected in the juridical texts such as the beginning of the Institutes of Gaius:

G 1 1: Omnes populi qui legibus et moribus reguntur, partim suo proprio, partim communi omnium hominum iure utuntur; nam quod quisque populis ipse sibi ius constituit, id ipsius proprium est vocaturque ius civile, quasi ius proprium civitatis; quod vero naturalis ratio 
inter omnes homines constituit, id apud omnes populos peraeque custoditur vocaturque ius gentium, quasi quo iure omnes gentes utuntur. Populus itaque Romanus partim suo proprio, partim communi omnium hominum iure utitur. Quae singula qualia sint, suis locis proponemus.

Every people that is governed by statutes and customs observes partly its own peculiar law and partly the common law of all mankind. That law which a people establishes for itself is peculiar to it and is called ius civile (civil law) as being the special law of that civitas (State), while the law that natural reason establishes among all mankind is followed by all peoples alike, and is called ius gentium (law of nations, or law of the world) as being the law observed by all mankind. Thus the Roman people observes partly its own peculiar law and partly the common law of all mankind. This distinction we shall apply in detail at the proper places. (Translated by De Zulueta 1946. This text is lacking in the Verona palimpsest, but can be reconstructed with the help of D 119.)

Ius gentium (Gaius does not mention ius naturale ${ }^{29}$ ) is only applicable between human beings. This text reminds us of the distinction which Aristotle made in the text that is quoted in EN V 1134 pp 9-24. The same applies for the following text which was written by the jurist Ulpian:

Ulp D 11 1 3-4: Ius naturale est quod natura omnia animalia docuit: nam ius istud non humani generis proprium sed omnium animalium quae in terra quae in mari nascuntur avium quoque commune est. Hinc descendit maris atque feminae coniunctio, quam nos matrimonium appellamus, hinc liberorum procreatio, hinc educatio: videmus etenim cetera quoque animalia, feras etiam istius iuris peritia censeri. 4. Ius gentium est, quo gentes humanae utuntur. Quod a naturali recedere facile intellegere licet, quia illud omnibus animalibus, hoc solis hominibus inter se commune sit.

Natural law is what nature has taught to all animals. For this law is not proper for human beings, but it is common for all animals which are born on earth or in the sea, and also for birds. From this is derived the union between man and woman which we call marriage, from this the breeding of children, from this education. We see indeed that knowledge of this law is attributed to all animals, even wild ones. 4. Ius gentium is the law which all peoples apply. It is easy to understand that this law differs from natural law, because the latter is common for all animals, the former is only common for human beings amongst each other. (Own translation.)

In a previous publication I have argued that the Roman division into ius gentium and ius naturale should be seen from that perspective..$^{30}$ It might be a consequence of the eclectical use of philosophy (of nature) by the Roman jurists. ${ }^{31}$ Brouwer has suggested that D 1113 could be compatible with Stoic philosophy as well. ${ }^{32}$ This point needs more attention. I hope to come back to this on another occasion.

29 See on this problem Wagner 1978: 51ff.

30 Winkel 1993: 443-449.

31 Ibid.

32 2015: 75 n 68 . 
6. The definition of Cicero on Natural Law forms the basis of Natural Law which is axiomatic for the seventeenth century and which was in medieval times further developed by Thomas Aquinas ${ }^{33}$ and later, for example, by Hugo Grotius who applied the Stoic doctrine of oikeiosis and had formulated some basic principles in the Prolegomena of De iure belli ac pacis:

Hugo Grotius De iure belli ac pacis Prol § 8: Haec vero quam rudi modo iam expressimus societatis custodia humano intellectui conveniens, fons est eius iuris, quod proprie tali nomine appellatur: quo pertinent alieni abstinentia, et si quid alieni habeamus aut lucri inde fecerimus restitutio, promissorum implendorum obligatio, damni culpa dati reparatio, et poenae inter homines meritum.

This maintenance of the social order, which we have roughly sketched, and which is consonant with human intelligence, is the source of law properly so called. To this sphere of law belong the abstaining from that which is another's, the restoration to another of anything of his which we may have, together with any gain which we may have received from it; the obligation to fulfill promises, the making of good of losses incurred though our fault, and the infliction of penalties upon men according to their deserts. (Translation FW Kelsey, Classics of International Law, 1925.)

In this text one can see the structure of patrimonial law; first of all the inviolability of property, unjustified enrichment and the two kinds of obligations: the contractual obligation and the delictual obligation. At the end of it, Grotius hints at the philosophical basis of criminal law.

7. This does not imply, however, that the pre-Socratic definition on natural law has totally disappeared. In the philosophical works of Macchiavelli, Spinoza, Thomas Hobbes, and Friedrich Nietzsche one can hear an echo of it or even find a renaissance thereof. ${ }^{34}$ All these philosophers have used the conception of Natural Law based on inequality. This double transmission of Natural Law remained visible until the twentieth century. Carl Schmitt and the NS ideology "hail" Natural Law based on the inequality for their doctrine on "Gesundes Volksempfinden", especially with regard to the application of the analogy in criminal law. In his inaugural lecture as professor in legal philosophy in Münster/Germany, Fabian Wittreck once again examined the foundations of Natural Law in the Nazi ideology. And in a very explicit way he has drawn our attention to a strange phenomenon, namely the continuity of the invocation of Natural Law. This phenomenon can only be explained by its variable contents. ${ }^{35}$ After World War II the German legal philosophers, remarkably enough, once again invoked the principles of natural equality as conceived by Cicero. ${ }^{36}$

33 Summa Theologiae Ia IIa 91 art 2.

34 Menzel 1922: 75ff [Anklänge an die Lehre von Kallikles in der Literatur der Neuzeit], 80ff [Kallikles und Nietzsche]; see, further, Wolf 1959: 89 [Machiavelli]; 41 and 88 [Spinoza]; 142ff [Hobbes]; 90 [Nietzsche].

35 Wittreck 2008.

36 See Hommes 1961. Natural law as an academic topic seems to revive in recent years, see, eg, Finnis 1984; an historical and theoretical analysis of natural law philosophy is given by Westerman 1997. 
In this respect Gustav Radbruch ${ }^{37}$ should be mentioned here, as well as Hans Wenzel $^{18}$ and Helmut Coing ${ }^{39}$ in their advocacy for a conception of Natural Law based on equality. Only the ambiguity of the concepts of Natural Law can explain the fact that Natural Law can be used to support juridical orders which are so very different. ${ }^{40}$

Erik Wolf's position is more difficult to understand. In the beginning of the Nazi regime he was a strong supporter of the new Nazi ideology; later, from 1937 on, however, he adhered to the anti-Nazist Bekennende Kirche of Dittrich Bonhoefer. ${ }^{41}$

8. Maybe another example of the double tradition of Natural Law concepts is visible in the political history of South Africa in the twentieth century where we find, on the one hand, the doctrine of apartheid (the invocation of natural inequality) since 1948 , and, on the other hand, after the constitutional changes the great importance on human rights - a new form of Natural Law philosophy based on human equality - in the South African Constitution of $1996 .{ }^{42}$

\section{BIBLIOGRAPHY}

Algra, Keimpe (2003) "The mechanism of social appropriation and its role in Hellenistic ethics" in Oxford Studies in Ancient Philosophy XXV (Oxford): 265-296

Brauneder, Wilhelm (1994) “Menzel, Adolf” Neue Deutsche Biographie 17 (Berlin): 104

Brouwer, René, (2015) "Ulpian's appeal to nature: Roman law as universal law", The Legal History Review 83: 60-76

Büchner, Karl (1984) M Tullius Cicero: De re publica - Kommentar (Heidelberg)

Coing, Helmut (1947) Die obersten Grundsätze des Rechts (Heidelberg)

Dalfen, Joachim (2004) Plato: Gorgias - Übersetzung und Kommentar (Göttingen)

Donati, Alberto (1990) Elementa iuris naturalis (Napoli)

Düring, Ingemar (1966) Aristoteles, Darstellung und Interpretation seines Denkens (Heidelberg)

Finnis, John (1984) Natural Law and Natural Rights (Oxford)

Flückiger, Felix (1954) Geschichte des Naturrechts, I: Altertum und Frühmittelalter (Zürich)

Forschner, Maximilian (1980) Die Stoische Ethik (Darmstadt)

Of course there are objections to this revival, for example in the doctrine Neo-Kantian positivists like Hans Kelsen; see further Wild 1953.

37 Radbruch 1946: 105-108.

38 Welzel 1967.

39 Coing 1947.

40 It is - to say the least - astonishing that Erik Wolf does not mention the invocation of natural law during Nazism in Germany (1933-1945) in his book quoted in $n 4$.

41 Idem.

42 Kleyn 1999: 30ff. 


\section{LAURENS WINKEL}

Frede, Michael (1996) “Aristotle's rationalism” in Rationality in Greek Thought, Frede, Michael \& Striker, Gisela (eds) (Oxford): 157-174

Guthrie, William (1962 repr 1978) A History of Greek Philosophy I: The Eearlier Presocratics and the Pythagoreans (Cambridge)

Hardie, William (1980) Aristotle's Ethical Theory (Oxford)

Heinimann, Felix (1945 repr 1978) Nomos und Physis (Basel)

Hoffmann, Klaus (1977) Das Recht im Denken der Sophistik (Stuttgart/Leipzig)

Hollerbach, Alexander (1979) "In memoriam Erik Wolf" in Zeitschrift der Savigny-Stiftung für Kanonistische Abteilung 65: 455-461

Hommes, Hendrik Jan (1961) Een nieuwe herleving van het natuurrecht (Zwolle)

Horsley, Richard (1978) "The law of nature in Philo and Cicero" in Harvard Theological Review 71: $35-59$

Irwin, Terence (1979) Plato: Gorgias (Oxford)

Jones, John (1956 repr. 1977) Law and Legal Theory of the Greeks (Oxford)

Kleyn, Duard (1999) Phenomena surrounding the acceptance of a new legal text: The rediscovery of Justinian's Corpus Iuris and the new South-African Constitution (Inaugural lecture as a Guest Professor at Erasmus University, Rotterdam) (Rotterdam)

Klose, Alfred, Schambeck, Herbert \& Weiler, Rudolf (eds) (1985) Das Neue Naturrecht, Gedächtnisschrift für Johannes Messmer (Berlin)

Long, Anthony \& Sedley, David (2009a) The Hellenistic Philosophers I (Cambridge)

Long, Anthony \& Sedley, David (2009b) The Hellenistic Philosophers II (Cambridge)

Manthe, Ulrich (1996) "Beiträge zur Entwicklung des antiken Gerechtigkeitsbegriffes I: Die Mathematisierung durch Pythagoras und Aristoteles" Zeitschrift der Savigny-Stiftung für Romanistische Abteilung 113: 1-31

Manthe, Ulrich (1997) "Beiträge zur antiken Gerechtigkeitsbegriffs II: Stoische Würdigkeit und die praecepta Ulpians", Zeitschrift der Savigny-Stiftung für Romanistische Abteilung 114: $1-26$

Menzel, Adolf (1922) Kallikles, Eine Studie zur Geschichte der Lehre vom Rechte des Stärkeren (Wien/Leipzig)

Messmer, Johannes (1950) Das Naturrecht, Handbuch der Gesellschaftsethik, Staatsethik und Wirtschaftsethik (Innsbruck/Wien)

Müller, Ingo (1987) Furchtbare Juristen (München)

Pizzorni, Reginaldo (1985) “La conoscenza della legge o diritto naturale 'per connaturalitatem' o 'per ínclinationem' Apollinaris 58: 47-67

Praechter, Karl (1926 repr 1967) Friedrich Ueberwegs Grundriss der Geschichte der Philosophie, Erster Band: Die Philosophie des Altertums (Darmstadt)

Radbruch, Gustav (1946) Süddeutsche Juristenzeitung 1: 105-108 - Radbruch, Gustav (1975) "Gesetzliches Unrecht und übergesetzliches Recht" in Rechtsphilosophie Wolf, Erik \& Schneider, Hans-Peter (eds) (Stuttgart): 339-350

De Romilly, Jacqueline (1989) La loi dans la pensée grecque (Paris)

Schrage, Eltjo (1975) Libertas est facultas naturalis (Leiden) 
Sorabji, Richard (1996) "Rationality" in Rationality in Greek Thought Frede, Michael \& Striker, Gisela (eds) (Oxford): 311-334

Schröder, Jan (2004) “Gesetz” und "Naturgesetz" in der frühen Neuzeit (Stuttgart)

Stammler, Rudolf (1902) Die Lehre von dem richtigen Rechte (Berlin)

Villey, Michel (1953) "Deux conceptions du droit naturel dans l'Antiquité" Revue historique de droit français et étranger 4 31: 475-497

Wagner, Herbert (1978) Studien zur allgemeinen Rechtslehre des Gaius, Ius gentium und ius naturale in ihrem Verhältnis zum ius civile (Zutphen)

Waldstein, Wolfgang (2010) Ins Herz geschrieben: Das Naturrecht als Fundament einer menschlichen Gesellschaft (Augsburg)

Welzel, Hans (1967) Naturrecht und materiale Gerechtigkeit (Göttingen)

Westerman, Pauline (1997) The Disintegration of Natural Law Theory (Leiden)

Wild, John (1953) Plato's Modern Enemies and the Theory of Natural Law (Chicago)

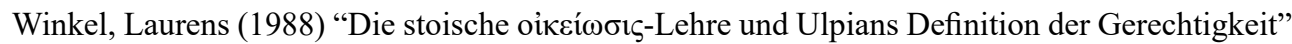
Zeitschrift der Savigny-Stiftung für Romanistische Abteilung 105: 669-679

Winkel, Laurens (1993) "Einige Bemerkungen über ius naturale und ius gentium" in Ius est ars boni et aequi. Festschrift für Wolfgang Waldstein Schermaier, Martin \& Végh, Zoltán (eds) (Karlsruhe): 443-449

Winkel, Laurens (2000) "Review of Hoffmann 1977” in Zeitschrift der Savigny-Stiftung für Romanistische Abteilung 117: 585-488

Fabian Wittreck, Nazionalsozialistische Rechtslehre und Naturrecht (2008)

Wolf, Erik (1959) Das Problem der Naturrechtslehre, Versuch einer Orientierung (Karlsruhe) 